\title{
Spectroscopic Study of the Hydration Equilibria and Water Exchange Dynamics of Lanthanide(III) Complexes of 1,7-Bis(carboxymethyl)-1,4,7,10- tetraazacyclododecane (DO2A)
}

\author{
Fabrice Yerly, ${ }^{[a]}$ Frank A. Dunand, ${ }^{[a]}$ Éva Tóth, ${ }^{[a]}$ Artur Figueirinha, ${ }^{[b]}$ Zoltán Kovács, ${ }^{[c]}$ \\ A. Dean Sherry, ${ }^{[d]}$ Carlos F. G. C. Geraldes, ${ }^{*[b]}$ and André E. Merbach*[a]
}

Keywords: Imaging agents / Lanthanides / NMR spectroscopy / DNA cleavage

The hydration state of a series of $\left[\mathrm{Ln}(\mathrm{DO} 2 \mathrm{~A})\left(\mathrm{H}_{2} \mathrm{O}\right)_{n}\right]^{+}$complexes in aqueous solution at $\mathrm{pH}=6.4-7.0$ was studied by measuring the lanthanide-induced ${ }^{17} \mathrm{O}$ shifts (LIS) of water [Ln includes elements from Ce to $\mathrm{Yb}$; DO2A = 1,7-bis(carboxymethyl)-1,4,7,10-tetraazacyclododecane]. Their contact contribution, obtained from Reilley plots, indicated a decrease in the inner-sphere water coordination number of the $\left[\mathrm{Ln}(\mathrm{DO} 2 \mathrm{~A})\left(\mathrm{H}_{2} \mathrm{O}\right)_{n}\right]^{+}$complexes from $n=3(\mathrm{Ce}-\mathrm{Eu})$, to $n=2$ $(\mathrm{Tb}-\mathrm{Yb})$. A temperature-dependent UV/Vis absorption study of the $578-582 \mathrm{~nm} \quad{ }^{7} \mathrm{~F}_{0} \rightarrow{ }^{5} \mathrm{D}_{0}$ transition band of $\left[\mathrm{Eu}(\mathrm{DO} 2 \mathrm{~A})\left(\mathrm{H}_{2} \mathrm{O}\right)_{n}\right]^{+}$in aqueous solution showed that this complex is present in an equilibrium between eight- and nine-coordinate species with $n=2$ and $n=3$, respectively. The hydration equilibrium parameters $(2 \rightleftarrows 3), K_{2-3}{ }^{298}=4.0 \pm$ $0.2, \Delta H_{2-3}{ }^{0}=-12.1 \pm 1 \mathrm{~kJ} \mathrm{~mol}^{-1}$ and $\Delta S_{2-3}^{0}=-28.9 \pm 3 \mathrm{~J} \mathrm{~mol}^{-}$ ${ }^{1} \mathrm{~K}^{-1}$, correspond to an average hydration number of 2.65
2.85 in the temperature range 273-363 K. A variable temperature, multiple field ${ }^{17} \mathrm{O}$ NMR study combined with direct EPR measurements of the transverse electronic relaxation rates has been used to obtain the parameters characterizing water exchange, rotation and electronic relaxation, all influencing the proton relaxivity of $\left[\mathrm{Gd}(\mathrm{DO} 2 \mathrm{~A})\left(\mathrm{H}_{2} \mathrm{O}\right)_{2-3}\right]^{+}$. The small increase in the water exchange rate of $\left[\mathrm{Gd}(\mathrm{DO} 2 \mathrm{~A})\left(\mathrm{H}_{2} \mathrm{O}\right)_{2-3}\right]^{+}\left(k_{\mathrm{ex}}^{298}=(10 \pm 5) \times 10^{6} \mathrm{~s}^{-1}\right)$ relative to that of $\left[\mathrm{Gd}(\mathrm{DOTA})\left(\mathrm{H}_{2} \mathrm{O}\right)\right]^{-}\left(4.8 \times 10^{6} \mathrm{~s}^{-1}\right)$ is a consequence of an unfavorable interplay of charge and hydration equilibria. The value of $\tau_{\mathrm{R}}^{298}=40 \pm 1 \mathrm{ps}$ is short, and the electronic relaxation rate $\left(1 / T_{2 \mathrm{e}} \approx 1.2 \times 10^{10} \mathrm{~s}^{-1}\right)$ is fast relative to $\left[\mathrm{Gd}(\mathrm{DOTA})\left(\mathrm{H}_{2} \mathrm{O}\right)\right]^{-}\left(1.3-2.4 \times 10^{9} \mathrm{~s}^{-1}\right.$ for $\left.B=0.34 \mathrm{~T}\right)$. These parameters negate to some extent the expected increase in proton relaxivity of the $\left[\mathrm{Gd}(\mathrm{DO} 2 \mathrm{~A})\left(\mathrm{H}_{2} \mathrm{O}\right)_{2-3}\right]^{+}$complex.

\section{Introduction}

There is a continued strong interest in the synthesis and characterization of trivalent lanthanide complexes, largely driven by biological and medical applications in magnetic resonance imaging (MRI), ${ }^{[1]} \mathrm{NMR}$ shift reagents, ${ }^{[2]}$ luminescence probes ${ }^{[3]}$ and DNA/RNA cleavage agents. ${ }^{[4]}$ Macrocyclic ligands are often targeted because they form thermodynamically and kinetically stable complexes with $\mathrm{Ln}^{3+}$ ions, thereby making them particularly attractive for these types of biomedical applications. A classic example is the $\left[\mathrm{Gd}(\mathrm{DOTA})\left(\mathrm{H}_{2} \mathrm{O}\right)\right]^{-}$complex, a widely used MRI contrast agent $[\mathrm{DOTA}=1,4,7,10$-tetrakis(carboxymethyl)-1,4,7,10-

[a] Institute of Inorganic and Analytical Chemistry,

University of Lausanne, BCH,

CH-1015 Lausanne, Switzerland

[b] Department of Biochemistry, Faculty of Science and

Technology, and Center of Neurosciences,

University of Coimbra,

Apartado 3126, 3000 Coimbra, Portugal

[c] Department of Chemistry, The University of Texas at Dallas, P. O. Box 830688, Richardson, TX 75083-0688, U.S.A.

[d] See address [c] and The Mary Nell and Ralph B. Rogers Magnetic Resonance Center, Department of Radiology, University of Texas Southwestern Medical Center, 5801 Forest Park Rd., Dallas, TX 75235-9085, U.S.A.

$\square$ Supporting information for this article is available on the WWW under http://www.wiley-vch.de/home/eurjic or from the author. tetraazacyclododecane]. One feature of [ $\left.\mathrm{Gd}(\mathrm{DOTA})\left(\mathrm{H}_{2} \mathrm{O}\right)\right]^{-}$ that is common to most other commercially available contrast agents is its lack of tissue specificity. One approach to obtain tissue-specific MRI contrast agents has been the synthesis of positively charged $\mathrm{Gd}^{\mathrm{III}}$ complexes which target bone tissue. ${ }^{[5]}$ It has been proposed that the mechanism of bone uptake is related to the ability of positively charged complexes to mimic biological cations $\left(\mathrm{Ca}^{2+}, \mathrm{K}^{+}\right.$, etc. $)$in their interactions with anionic bone surfaces. ${ }^{[5 \mathrm{~b}]}$ Cationic complexes also serve as candidates for DNA/RNA ribonuclease mimics, provided they have free coordination sites (inner-sphere waters) available to coordinate with nucleotides. ${ }^{[6]}$ Removal of one or two carboxylates from the ligand DOTA results in a decrease in complex stability and an increase in the number of inner-sphere water molecules [see structures of DO3A $=1,4,7$-tris(carboxymethyl)1,4,7,10-tetraazacyclododecane and DO2A $=1,7$-bis(carboxymethyl)-1,4,7,10-tetraazacyclododecane in Scheme 1].

A recent UV/Vis study of $\left[\mathrm{Eu}(\mathrm{DO} 3 \mathrm{~A})\left(\mathrm{H}_{2} \mathrm{O}\right)_{n}\right]$ has shown that in aqueous solution this complex is present in an equilibrium between eight- and nine-coordinate species having one and two inner-sphere water molecules, respectively. ${ }^{[7]}$ Among other parameters, including the rate of molecular tumbling and electronic relaxation, the exchange rate of these coordinated water molecules is an important factor in 
<smiles>O=C(O)CN1CCNCCN(CC(=O)O)CCNCC1</smiles>

DO2A

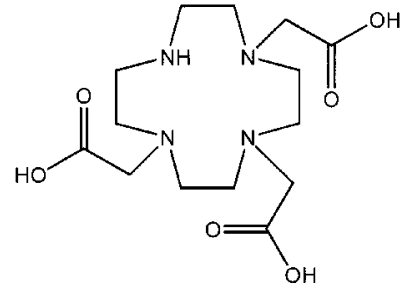

DO3A

Scheme 1. Structure of the ligands DO2A and DO3A

determining the proton relaxivity, hence the efficiency of the $\mathrm{Gd}^{\mathrm{III}}$ complex as an MRI contrast agent.

The objective of this work was to study the hydration state of several $\left[\mathrm{Ln}(\mathrm{DO} 2 \mathrm{~A})\left(\mathrm{H}_{2} \mathrm{O}\right)_{n}\right]^{+}$complexes and to evaluate the factors that influence the proton relaxivity of $\left[\mathrm{Gd}(\mathrm{DO} 2 \mathrm{~A})\left(\mathrm{H}_{2} \mathrm{O}\right)_{n}\right]^{+}$. Although the low stability constant recently reported for $\left[\mathrm{Gd}(\mathrm{DO} 2 \mathrm{~A})\left(\mathrm{H}_{2} \mathrm{O}\right)_{n}\right]^{+}{ }^{[8]}$ much lower than the value reported previously, ${ }^{[5 \mathrm{cc}]}$ indicates that this complex may not be suitable for biomedical applications, it serves as a useful model of a complex having more than a single inner-sphere water molecule, and the influence of this on water relaxivity. To get information on structural similarities or changes along the $\mathrm{Ln}^{\mathrm{III}}$ series, lanthanide induced ${ }^{17} \mathrm{O}$ shifts (LIS) of water have been measured for the whole series of lanthanide(III) DO2A complexes and analyzed in terms of Reilley plots. ${ }^{[9]}$ The UV/Vis spectra of $\left[\mathrm{Eu}(\mathrm{DO} 2 \mathrm{~A})\left(\mathrm{H}_{2} \mathrm{O}\right)_{n}\right]^{+}$gave unambiguous evidence for the existence of a hydration equilibrium for this complex. A variable temperature, multiple field ${ }^{17} \mathrm{O}$ NMR study combined with direct measurements of the transverse electronic relaxation rates has been used to determine the water exchange rate of $\left[\mathrm{Gd}(\mathrm{DO} 2 \mathrm{~A})\left(\mathrm{H}_{2} \mathrm{O}\right)_{n}\right]^{+}$.

\section{Results and Discussion}

\section{Lanthanide Induced ${ }^{17} \mathrm{O}$ NMR Shift Measurements}

To obtain the number of inner-sphere water molecules, $\mathrm{n}$, in the $\left[\mathrm{Ln}(\mathrm{DO} 2 \mathrm{~A})\left(\mathrm{H}_{2} \mathrm{O}\right)_{\mathrm{n}}\right]^{+}$complexes, ${ }^{17} \mathrm{O}$ NMR chemical shifts were measured on $0.020 \mathrm{M}$ solutions of those complexes in $2 \%{ }^{17} \mathrm{O}$-enriched water $(\mathrm{Ln}=\mathrm{La}, \mathrm{Ce}, \mathrm{Pr}, \mathrm{Nd}, \mathrm{Eu}$, Dy, $\mathrm{Ho}, \mathrm{Er}, \mathrm{Yb}$ and $\mathrm{Lu}$ ), at $\mathrm{pH} 7-8,346 \mathrm{~K}$ and $9.4 \mathrm{~T}$. To ensure that the complexes are fully formed (for $0.020 \mathrm{M}$ solutions, at $\mathrm{pH}>7.8$ for the $\mathrm{La}^{\mathrm{III}}$ complex, at $\mathrm{pH}>6.8$ for the $\mathrm{Gd}^{\mathrm{III}}$ complex, and at $\mathrm{pH}>6.5$ for the $\mathrm{Lu}^{\mathrm{III}}$ complex), ${ }^{[8]}$ complexation was verified by ${ }^{1} \mathrm{H}$ NMR spectroscopy. As there are two conflicting reports on the thermodynamic stability constant for $\left[\mathrm{Gd}(\mathrm{DO} 2 \mathrm{~A})\left(\mathrm{H}_{2} \mathrm{O}\right)_{n}\right]^{+},{ }^{[5 c, 8]}$ the lower stability constant value was assumed when preparing the complexes so as to ensure that all metal was complexed. Although some complexes may have one partially hydrolyzed, inner-sphere water molecule under the conditions used here (the value of the hydrolysis constant obtained for the $\left[\mathrm{Eu}(\mathrm{DO} 2 \mathrm{~A})\left(\mathrm{H}_{2} \mathrm{O}\right)_{n}\right]^{+}$complex has been reported to be $\left.\mathrm{p} K_{\mathrm{a}}^{\mathrm{Eu}}=8.1 \pm 0.3\right),{ }^{[8]}$ such ionization would not affect the measured ${ }^{17} \mathrm{O}$ shift values of bulk water. ${ }^{[\mathrm{b}]}$

The ${ }^{17} \mathrm{O}$ shift $(\Delta)$ of water in the presence of a paramagnetic complex has diamagnetic $\left(\Delta_{\mathrm{d}}\right)$, contact $\left(\Delta_{\mathrm{c}}\right)$ and pseudocontact contributions $\left(\Delta_{\mathrm{p}}\right) .^{[1 \mathrm{~b}]}$ The value of $\Delta_{\mathrm{d}}$ was taken as the average shift observed in the $\mathrm{La}^{3+}$ and $\mathrm{Lu}^{3+}$ complexes. The remaining sum, $\Delta_{\mathrm{c}}+\Delta_{\mathrm{p}}$, can be expressed as a product of terms, one characteristic of the $\mathrm{Ln}^{3+}$ ion but independent of the structure of the complex $\left(<S_{z}\right\rangle$ and $C^{\mathrm{D}}$, respectively) and another characteristic of the complex but independent of the $\mathrm{Ln}^{3+}$ ion ( $F$ and $G$, respectively). Thus, the paramagnetic shift induced by the lanthanide (LIS) $\Delta^{\prime}$ is given by Equation $1:[1 \mathrm{~b}, 10,11]$

$\Delta^{\prime}=\Delta-\Delta_{\mathrm{d}}=\Delta_{\mathrm{c}}+\Delta_{\mathrm{p}}=<S_{z}>F+C^{D} G$

Values of $\left\langle S_{z}\right\rangle$ and $C^{D}$ were taken from the literature $^{[10,11]}$ and Equation 1 was rearranged into a linear form to give Equation $2:{ }^{[9,12]}$

$\Delta^{\prime} / C^{D}=<S_{z}>F / C^{D}+G$

For an isostructural series of $\mathrm{Ln}^{3+}$ complexes, a plot of $\Delta^{\prime} / C^{D}$ vs. $<S_{z}>/ C^{D}$ should be linear. Deviations from linearity have been taken as evidence for a change in structure along the $\mathrm{Ln}^{\mathrm{III}}$ series. ${ }^{[1 \mathrm{~b}, 9,12]}$

The observed ${ }^{17} \mathrm{O}$ LIS values of water at $346 \mathrm{~K}$ were extrapolated to $\rho_{\mathrm{W}}=[\mathrm{Ln}] /\left[\mathrm{H}_{2} \mathrm{O}\right]=1$. Since water exchange between the bulk and the inner coordination sphere of the $\left[\mathrm{Ln}(\mathrm{DO} 2 \mathrm{~A})\left(\mathrm{H}_{2} \mathrm{O}\right)_{\mathrm{n}}\right]^{+}$complexes is fast, ${ }^{[5 \mathrm{c}]}$ the extrapolated ${ }^{17} \mathrm{O}$ shift values correspond to $\mathrm{n} \Delta .{ }^{[13]} \mathrm{A}$ plot of ${ }^{17} \mathrm{O}$ shifts according to Equation 2 does not follow a single linear correlation but rather divides into two groups (Ce-Eu and Dy$\mathrm{Yb}$ ) with a "break" near the middle of the lanthanide series (see Figure 1).

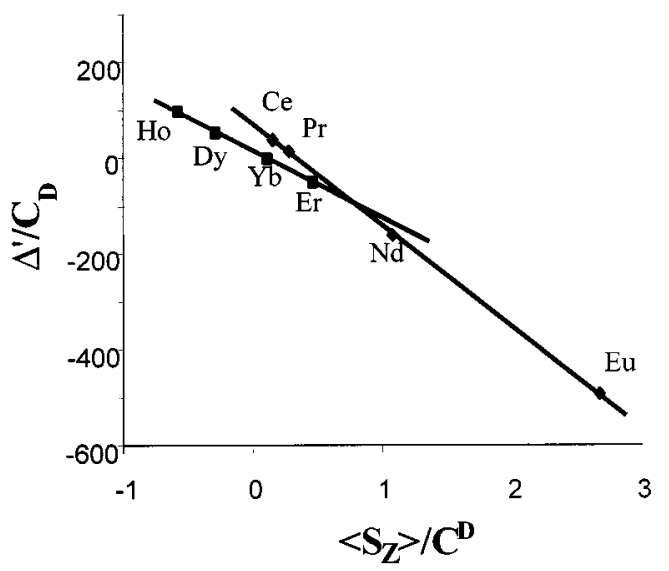

Figure 1. Plot of $\Delta^{\prime} / C^{D}$ versus $<S_{z}>/ C^{D}$ for the ${ }^{17} \mathrm{O}$ resonance of the $\left[\mathrm{Ln}(\mathrm{DO} 2 \mathrm{~A})\left(\mathrm{H}_{2} \mathrm{O}\right)_{n}\right]$ complexes at $346 \mathrm{~K}$

Such a break could reflect a change in the water coordination number of the complexes along the lanthanide series. A linear regression analysis ${ }^{[9]}$ of the two sets of data gives $\mathrm{n} F=-211 \pm 1$ and $\mathrm{n} G=72.5 \pm 2.1$ for $\mathrm{Ln}=\mathrm{Ce}-$ $\mathrm{Eu}$, and $\mathrm{n} F=-140 \pm 4$ and $\mathrm{n} G=12.2 \pm 1.7$ for $\mathrm{Ln}=$ $\mathrm{Dy}-\mathrm{Yb}$. The ${ }^{17} \mathrm{O}$ LIS of the coordinated water molecules is dominated by the contact contribution ${ }^{[1 b]}$ as shown by the large $F$ values. The values of $F$ for $\mathrm{Ln}^{3+}$-bound ${ }^{17} \mathrm{O}$ nuclei are known to be rather constant at $-70 \pm 11$ at $346 \mathrm{~K} .{ }^{[1 b, 13]}$ Using this constant and the values of $\mathrm{n} F$ obtained from the plot, values of $n=3 \pm 0.3$ and $n=2 \pm 0.3$ were estimated 
for the $\mathrm{Ce}-\mathrm{Eu}$ and $\mathrm{Dy}-\mathrm{Yb}$ series, respectively. The value of $n=2$ for the heavier $\mathrm{Ln}$ ion complexes agrees with the previously published value for $\left[\mathrm{Dy}(\mathrm{DO} 2 \mathrm{~A})\left(\mathrm{H}_{2} \mathrm{O}\right)_{\mathrm{n}}\right]^{+}$derived from a ${ }^{17} \mathrm{O}$ shift titration. ${ }^{[5]}$ The calculated values of $\mathrm{n} G$ and $\mathrm{n}$ also led us to values of $G=21.2 \pm 0.7$ for $\mathrm{Ce}-\mathrm{Eu}$ and $G=6.1 \pm 0.8$ for $\mathrm{Dy}-\mathrm{Yb}$. This decrease in the average geometric term $G$ for the ${ }^{17} \mathrm{O}$ nuclei of the coordinated water molecules from the first to the second half of the $\mathrm{Ln}$ series is also in agreement with the proposed decrease in the water coordination number. In fact, the change of $n=$ 3 , with a possible monocapped square antiprismatic coordination geometry of the $\mathrm{Ln}$ ion in $\left[\mathrm{Ln}(\mathrm{DO} 2 \mathrm{~A})\left(\mathrm{H}_{2} \mathrm{O}\right)_{3}\right]^{+}$, to $n=2$, with a possible square antiprismatic coordination geometry of the $\mathrm{Ln}$ ion in $\left[\mathrm{Ln}(\mathrm{DO} 2 \mathrm{~A})\left(\mathrm{H}_{2} \mathrm{O}\right)_{2}\right]^{+}$, would correspond to a loss of the water molecule in the capping position. This coordination position makes the largest contribution to the $G$ value.

\section{UV/Vis Measurements}

The ${ }^{17} \mathrm{O}$ LIS measurements indicated that a structural change occurs in the middle of the $\mathrm{Ln}^{\mathrm{III}}$ series near Eu${ }^{\mathrm{III}}$. $\mathrm{Eu}^{\mathrm{III}}$ has a transition band in the visible spectrum at 578 $582 \mathrm{~nm}\left({ }^{7} \mathrm{~F}_{0} \rightarrow{ }^{5} \mathrm{D}_{0}\right)$ which is very sensitive to changes in the coordination environment and has been previously used to characterize coordination equilibria for $\mathrm{Eu}^{\mathrm{III}}$ complexes. ${ }^{[7,14,15]}$ In accordance with the ${ }^{17} \mathrm{O}$ LIS measurements, the UV/Vis spectrum of a $\left[\mathrm{Eu}(\mathrm{DO} 2 \mathrm{~A})\left(\mathrm{H}_{2} \mathrm{O}\right)_{\mathrm{n}}\right]^{+}$solution clearly shows the presence of two coordination species (a representative spectrum is given in Figure 2).

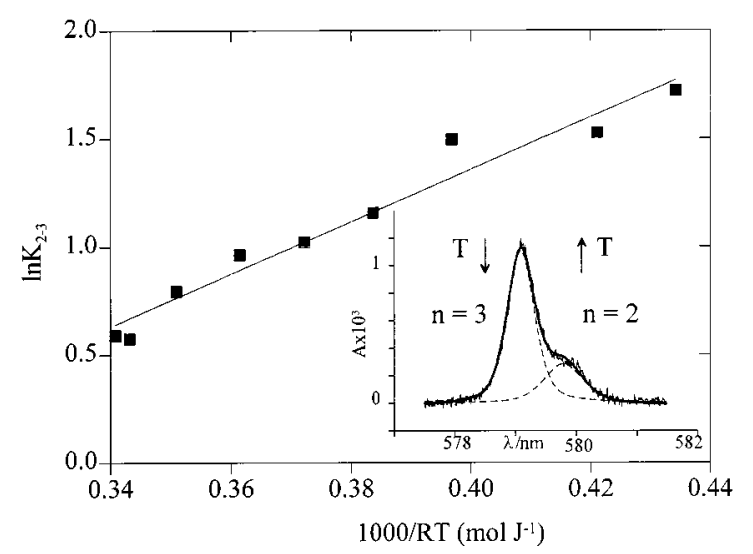

Figure 2. Ratio of the integrals of the two transition bands $(n=2$ and $n=3)$ in the UV/Vis spectrum of $\left[\mathrm{Eu}(\mathrm{DO} 2 \mathrm{~A})\left(\mathrm{H}_{2} \mathrm{O}\right)_{n}\right]^{+}$as a function of the inverse temperature; the line represents a linear least-squares fit to the data points; the resulting parameters are $\Delta H^{0}=-12.1 \pm 1 \mathrm{~kJ} \mathrm{~mol}^{-1}, \Delta S^{0}=-28.9 \pm 3 \mathrm{~J} \mathrm{~mol}^{-1} \mathrm{~K}^{-1}$; the inserted figure shows a typical UV/Vis spectrum of the $\mathrm{Eu}^{3+}{ }^{7} \mathrm{~F}_{0}$ $\rightarrow{ }^{5} \mathrm{D}_{0}$ transition in a $\left[\mathrm{Eu}(\mathrm{DO} 2 \mathrm{~A})\left(\mathrm{H}_{2} \mathrm{O}\right)_{n}\right]^{+}$solution $(T=323.0 \mathrm{~K}$; $\left.\mathrm{c}_{\mathrm{Eu}}=0.01 \mathrm{M}\right)$; the dashed lines represent the fitted contributions of the two peaks to the overall spectrum, itself given by the solid line

Chang et al. recently published a $\mathrm{pH}$-dependent luminescence study of $\left[\mathrm{Eu}(\mathrm{DO} 2 \mathrm{~A})\left(\mathrm{H}_{2} \mathrm{O}\right)_{\mathrm{n}}\right]^{+}$in the $\mathrm{pH}$ range $5.2-$ 9.6 (ambient temperature). ${ }^{[8]}$ The luminescence spectra present two bands of varying intensity as a function of $\mathrm{pH}$, assigned to the $\left[\mathrm{Eu}(\mathrm{DO} 2 \mathrm{~A})\left(\mathrm{H}_{2} \mathrm{O}\right)_{3}\right]^{+}$and $[\mathrm{Eu}(\mathrm{DO} 2 \mathrm{~A})-$ $\left.\left(\mathrm{H}_{2} \mathrm{O}\right)_{2}(\mathrm{OH})\right]$ species. Based on the relative peak intensities, they estimated a hydrolysis constant of $8.1 \pm 0.3\left(\mathrm{p} K_{\mathrm{a}}\right)$.
Since the $\mathrm{pH}$ of our $\left[\mathrm{Eu}(\mathrm{DO} 2 \mathrm{~A})\left(\mathrm{H}_{2} \mathrm{O}\right)_{n}\right]^{+}$sample was 6.4, the amount of any deprotonated complex would be negligible and hence this cannot explain the second absorption band in the spectrum. Moreover, the intensity of one band increases while that of the other decreases with increasing temperature, a feature characteristic of hydration equilibria. Since DO2A ${ }^{2-}$ has 6 donor atoms and coordination numbers of 8 or 9 are generally observed for $\mathrm{Eu}^{\mathrm{III}}$ complexes, the equilibrium can be depicted as shown in Equation 3:

$\left[\mathrm{Eu}(\mathrm{DO} 2 \mathrm{~A})\left(\mathrm{H}_{2} \mathrm{O}\right)_{2}\right]^{+}+\mathrm{H}_{2} \mathrm{O} \rightleftarrows\left[\mathrm{Eu}(\mathrm{DO} 2 \mathrm{~A})\left(\mathrm{H}_{2} \mathrm{O}\right)_{3}\right]^{+}$

A comparison of the position of the two transition bands with those of previously studied 8- and 9-coordinate $\mathrm{Eu}^{\mathrm{III}}$ poly(aminocarboxylate) complexes ${ }^{[7,15]}$ is consistent with this assignment. The band at $\lambda_{\max } \approx 579.8 \mathrm{~nm}$, which gains intensity with increasing temperature, is assigned to the complex of lower coordination number, $\left[\mathrm{Eu}(\mathrm{DO} 2 \mathrm{~A})\left(\mathrm{H}_{2} \mathrm{O}\right)_{2}\right]^{+}$, while the band at $\lambda_{\max } \approx 579.0 \mathrm{~nm}$ can be assigned to $\left[\mathrm{Eu}(\mathrm{DO} 2 \mathrm{~A})\left(\mathrm{H}_{2} \mathrm{O}\right)_{3}\right]^{+}$.

The hydration equilibrium constant is defined by Equation 4:

$K_{2-3}=\frac{\left[E u(D O 2 A)\left(\mathrm{H}_{2} \mathrm{O}\right)_{3}\right]^{+}}{\left[\operatorname{Eu}(\mathrm{DO} 2 \mathrm{~A})\left(\mathrm{H}_{2} \mathrm{O}\right)_{2}\right]^{+}}$

The reaction enthalpy, $\Delta H_{2-3}{ }^{\circ}$, and the reaction entropy, $\Delta S_{2-3}{ }^{\circ}$, for the equilibrium can be obtained from the temperature dependence of $K_{2-3}$ (Equation 5):

$\ln K_{2-3}=\frac{\Delta S_{2-3}^{0}}{R}-\frac{\Delta H_{2-3}^{0}}{R T}$

The spectra were analyzed with a program developed in our laboratory, ${ }^{[15]}$ which relates the ratio of the integrals of the two bands to the equilibrium constant. The temperature dependence of the ratio of the band integrals is presented in Figure 2. A fitting of the data to Equation 5 gave values for $\Delta H_{2-3}^{0}=-12.1 \pm 1 \mathrm{~kJ} \mathrm{~mol}^{-1}, \Delta S_{2-3}^{0}=-28.9 \pm 3 \mathrm{~J} \mathrm{~mol}^{-1}$ $\mathrm{K}^{-1}$ and $K_{2-3}^{298}=4.0 \pm 0.2$. This corresponds to an average hydration number of $2.65-2.85$ for $\left[\mathrm{Eu}(\mathrm{DO} 2 \mathrm{~A})\left(\mathrm{H}_{2} \mathrm{O}\right)_{2-3}\right]^{+}$ in the temperature range $273-363 \mathrm{~K}$.

It should also be noted that in the spectra reported by Chang et al., a small shoulder on one of the bands was present. Though not interpreted by the authors, it could represent differently hydrated species. In their study, the number of inner-sphere water molecules as determined by differences in excited-state lifetimes in $\mathrm{H}_{2} \mathrm{O}$ and $\mathrm{D}_{2} \mathrm{O}^{[16]}$ was found to be $n=3.0$ for the fully protonated species. However, it does not preclude the existence of a hydration equilibrium since the usual error in the value of $n$ determined by this method is approximately \pm 0.2 .

\section{${ }^{17} \mathrm{O}$ NMR and EPR Measurements}

Transverse and longitudinal ${ }^{17} \mathrm{O}$ relaxation rates and chemical shifts were measured for $\left[\mathrm{Gd}(\mathrm{DO} 2 \mathrm{~A})\left(\mathrm{H}_{2} \mathrm{O}\right)_{n}\right]^{+}$at 
1.41, 9.4 and $14.1 \mathrm{~T}$ as a function of temperature. The UV/ Vis measurements performed on the corresponding $\left[\mathrm{Eu}(\mathrm{DO} 2 \mathrm{~A})\left(\mathrm{H}_{2} \mathrm{O}\right)_{n}\right]^{+}$complex indicated that this complex is present in two hydrated forms. There is no direct method to study hydration equilibrium for a $\mathrm{Gd}^{\mathrm{III}}$ complex, so one can only rely on the results obtained for the nearest neighbor, $\mathrm{Eu}^{\mathrm{III}}$. In the case of $\left[\mathrm{Ln}(\mathrm{DO} 3 \mathrm{~A})\left(\mathrm{H}_{2} \mathrm{O}\right)_{n}\right]$, a luminescence study of the $\mathrm{Tb}^{\mathrm{III}}$ complex and the UV/Vis measurements on the corresponding $\mathrm{Eu}^{\mathrm{III}}$ chelate both resulted in similar values for the water coordination number $(n=$ 1.8 and 1.9 , respectively), indicating that it is reasonable to assume the same hydration equilibria for the $\mathrm{Gd}^{\mathrm{III}}$ and $\mathrm{Eu}^{\mathrm{III}}$ complexes. This means that in a solution of $\left[\mathrm{Gd}(\mathrm{DO} 2 \mathrm{~A})\left(\mathrm{H}_{2} \mathrm{O}\right)_{n}\right]^{+}$there are two species (the bis- and tris-hydrated complex) both of which can, in principle, exchange with bulk water. Consequently, any analysis of the transverse relaxation rates in this system should be treated as a three-site exchange problem.

We recently compared the analyses of ${ }^{17} \mathrm{O}$ NMR data of $\left[\mathrm{Gd}(\mathrm{DO} 3 \mathrm{~A})\left(\mathrm{H}_{2} \mathrm{O}\right)_{n}\right](n=1$ and 2$)$ performed with the rigorous three-site exchange approach using Kubo-Sack matrices versus the more typical Swift-Connick treatment by assuming a temperature-dependent value for the mole fraction of bound water. ${ }^{[7]}$ The two approaches gave the same results for parameters derived from the ${ }^{17} \mathrm{O}$ NMR data. This led us to conclude that, in such cases, where the equilibrium between the two differently hydrated species is strongly shifted towards one complex (for both $\left[\mathrm{Gd}(\mathrm{DO} 2 \mathrm{~A})\left(\mathrm{H}_{2} \mathrm{O}\right)_{n}\right]^{+}$and $\left[\mathrm{Gd}(\mathrm{DO} 3 \mathrm{~A})\left(\mathrm{H}_{2} \mathrm{O}\right)_{n}\right]$ it was the nine-coordinate complex), the simpler Swift-Connick treatment provides sufficiently precise results, and application of the more complicated Kubo-Sack formalism is not necessary. Therefore the present ${ }^{17} \mathrm{O}$ NMR data for $\left[\mathrm{Gd}(\mathrm{DO} 2 \mathrm{~A})\left(\mathrm{H}_{2} \mathrm{O}\right)_{\mathrm{n}}\right]^{+}$have been analyzed by means of the Swift-Connick equations, according to the method previously described. ${ }^{[7,17,18]}$ For the mole fraction of bound water $\left(P_{\mathrm{m}}\right)$, we used a temperature-dependent value calculated on the basis of $\Delta H_{2-3}^{0}$ and $\Delta S_{2-3}^{0}$ obtained for [Eu$\left.(\mathrm{DO} 2 \mathrm{~A})\left(\mathrm{H}_{2} \mathrm{O}\right)_{2-3}\right]^{+}$in the UV/Vis study. In the calculations, the electronic relaxation rates measured by EPR at $0.34 \mathrm{~T}$ (X-band) have been fitted simultaneously with the ${ }^{17} \mathrm{O}$ NMR data. The transverse electronic relaxation rate $(1.2 \pm$ $0.1 \times 10^{10} \mathrm{~s}^{-1}$ ) measured at $0.34 \mathrm{~T}$ was independent of temperature over the range $T=274-356 \mathrm{~K}$. The transverse ${ }^{17} \mathrm{O}$ relaxation rates and chemical shifts as well as the fitted curves are presented in Figure 3.

The fit resulted in the following parameters: $k_{\mathrm{ex}}^{298}=10 \pm$ $5 \times 10^{6} \mathrm{~s}^{-1}, \Delta H^{\neq}=21.3 \pm 4 \mathrm{~kJ} / \mathrm{mol}, \Delta S^{\neq}=-39 \pm 11 \mathrm{~kJ} /$ $\mathrm{mol} \tau_{\mathrm{R}}^{298}=40 \pm 1 \mathrm{ps}, E_{\mathrm{R}}=16.4 \pm 0.7 \mathrm{~kJ} / \mathrm{mol}, \tau_{\mathrm{v}}^{298}=16 \pm$ $1 \mathrm{ps}, E_{\mathrm{v}}=1.0 \mathrm{~kJ} / \mathrm{mol}, \Delta^{2}=1.06 \pm 0.02 \times 10^{20} \mathrm{~s}^{-2}$ and $A / \hbar=-3.4 \pm 0.2 \times 10^{6} \mathrm{rad} \mathrm{s}^{-1}$.

Previous ${ }^{17} \mathrm{O}$ NMR studies on numerous $\mathrm{Gd}^{\mathrm{III}}$ complexes have shown that the rate and mechanism of water exchange is strongly related to the inner-sphere structure of the chelate. These findings suggested that, for complexes with a hydration equilibrium, less energy is needed to pass from the reactant to the transition state since both are already present in solution. Thus, one might expect an increased

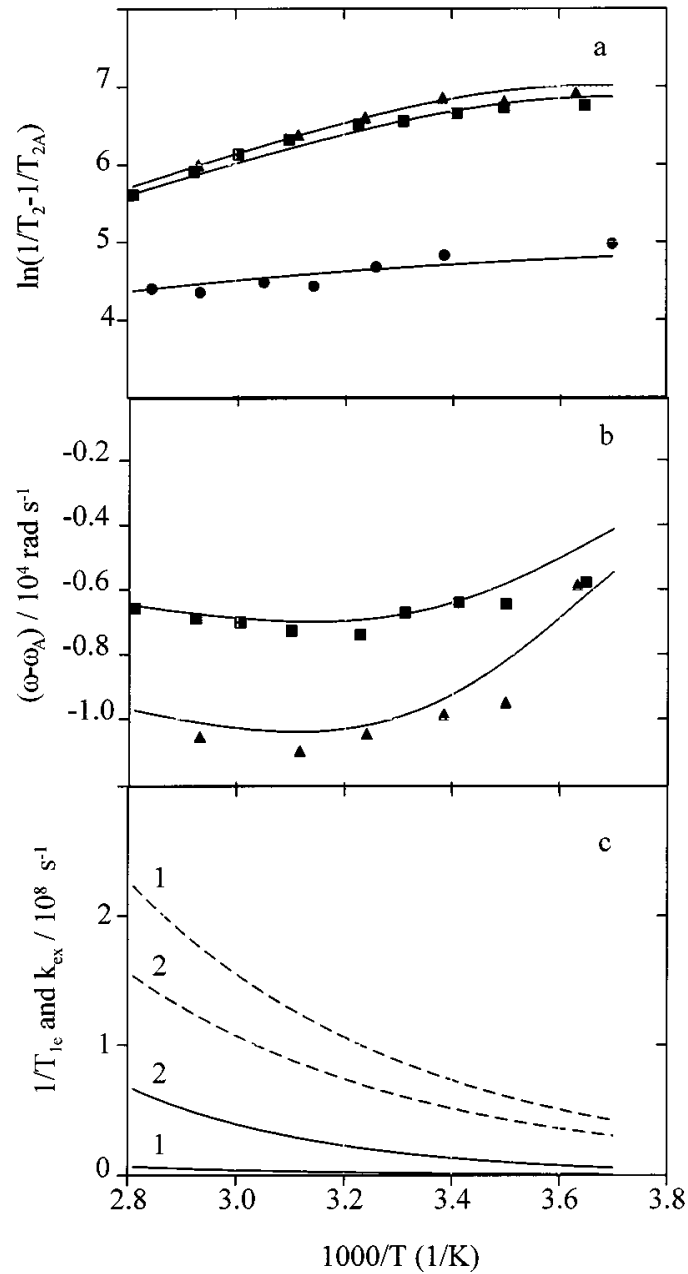

Figure 3. Temperature dependence of the transverse ${ }^{17} \mathrm{O}$ relaxation enhancements (a) and chemical shifts (b) at $\mathrm{B}=14.1 \mathrm{~T}(\sigma), 9.4 \mathrm{~T}$ ( $\mathrm{n})$ and $1.41 \mathrm{~T}$ (1); the solid lines correspond to the simultaneous least-squares fit to all data points according to the Swift and Connick equations using a temperature dependent $P_{\mathrm{m}}$ value; the lower part of the figure (c) represents $k_{\mathrm{ex}}$ (solid lines) and $1 / T_{\mathrm{le}}$ (dashed lines), the two contributions to the overall correlation time that governs the transverse ${ }^{17} \mathrm{O}$ relaxation, as computed for the two limiting cases of $k_{\mathrm{ex}}^{298}=5 \times 10^{6}(1)$ and $15 \times 10^{6} \mathrm{~s}^{-1}$ (2) (see text)

water exchange rate for $\left[\mathrm{Gd}(\mathrm{DO} 2 \mathrm{~A})\left(\mathrm{H}_{2} \mathrm{O}\right)_{2-3}\right]^{+}$than for a system like $\left[\mathrm{Gd}(\mathrm{DOTA})\left(\mathrm{H}_{2} \mathrm{O}\right)\right]^{-}$having a single hydrated species. Contrary to expectations for both $\left[\mathrm{Gd}(\mathrm{DO} 2 \mathrm{~A})\left(\mathrm{H}_{2} \mathrm{O}\right)_{2-3}\right]^{+}$and $\left[\mathrm{Gd}(\mathrm{DO} 3 \mathrm{~A})\left(\mathrm{H}_{2} \mathrm{O}\right)_{1-2}\right]$, only a limited gain in the water exchange rate was observed \{about two-fold compared with $\left[\mathrm{Gd}(\mathrm{DOTA})\left(\mathrm{H}_{2} \mathrm{O}\right)\right]^{-}\left(k_{\mathrm{ex}}^{298}=10 \times\right.$ $10^{6} \mathrm{~s}^{-1}$ and $11 \times 10^{6} \mathrm{~s}^{-1}$ for the DO2A and DO3A complexes, respectively, versus $4.8 \times 10^{6} \mathrm{~s}^{-1}$ for the DOTA complex) $\}.{ }^{[7]}$ However, a second confounding factor that one must consider in these complexes is the increase in overall positive charge on the DO3A and DO2A complexes. A previous study on the $\mathrm{Gd}^{\mathrm{III}}$ complex of the pentacarboxylate DOTASA ${ }^{5-}$ has clearly shown that a higher negative charge favors fast water exchange, as $k_{\mathrm{ex}}^{298}$ of [Gd(DOTASA) $\left.\left(\mathrm{H}_{2} \mathrm{O}\right)\right]^{2-}$ was about $50 \%$ higher than that of $[\mathrm{Gd}(\mathrm{DOT}-$ A) $\left.\left(\mathrm{H}_{2} \mathrm{O}\right)\right]^{-}\left(\mathrm{H}_{5}\right.$ DOTASA $=1,4,7,10$-tetraazacyclododecane-1-succinic acid-4,7,10-triacetic acid). ${ }^{[19]}$ A similar effect was observed upon substitution of one carboxylate of 
DOTA $^{4-}$ or DTPA ${ }^{5-}$ by noncharged amide groups. In both systems, the water exchange rate diminished by a factor of $3-4$. Thus, the limited increase in the water exchange rate of $\left[\mathrm{Gd}(\mathrm{DO} 2 \mathrm{~A})\left(\mathrm{H}_{2} \mathrm{O}\right)_{2-3}\right]^{+}$or $\left[\mathrm{Gd}(\mathrm{DO} 3 \mathrm{~A})\left(\mathrm{H}_{2} \mathrm{O}\right)_{1-2}\right]$ relative to that of $\left[\mathrm{Gd}(\mathrm{DOTA})\left(\mathrm{H}_{2} \mathrm{O}\right)\right]^{-}$must reflect two opposing effects: the favorable hydration equilibrium effect partially cancelled by the unfavorable charge effects.

The $k_{\text {ex }}$ values as cited above correspond to the exchange of one water molecule, hence the overall water exchange rate is about twice the $k_{\mathrm{ex}}$ of $\left[\mathrm{Gd}(\mathrm{DO} 3 \mathrm{~A})\left(\mathrm{H}_{2} \mathrm{O}\right)_{1-2}\right]$ (the average hydration number close to 2 ) and three times the $k_{\mathrm{ex}}$ of $\left[\mathrm{Gd}(\mathrm{DO} 2 \mathrm{~A})\left(\mathrm{H}_{2} \mathrm{O}\right)_{2-3}\right]^{+}$(the average hydration number close to 3$)$. Consequently, the overall water-exchange rates of $\left[\mathrm{Gd}(\mathrm{DO} 3 \mathrm{~A})\left(\mathrm{H}_{2} \mathrm{O}\right)_{1-2}\right]$ and $\left[\mathrm{Gd}(\mathrm{DO} 2 \mathrm{~A})\left(\mathrm{H}_{2} \mathrm{O}\right)_{2-3}\right]^{+}$relative to that of $\left[\mathrm{Gd}(\mathrm{DOTA})\left(\mathrm{H}_{2} \mathrm{O}\right)\right]^{-}$were greater by a factor 4 and 6 , respectively.

It should be noted that the error in $k_{\mathrm{ex}}^{298}$ determined in this study is exceptionally high. The reason lies in the unfavorable interplay of water exchange and electronic relaxation for this system. For $\left[\mathrm{Gd}(\mathrm{DO} 2 \mathrm{~A})\left(\mathrm{H}_{2} \mathrm{O}\right)_{2-3}\right]^{+}$, a slow exchange region, where the $1 / T_{2}$ values are directly proportional to the water exchange rate, does not exist over the temperature range examined (the transverse relaxation rate enhancement never increases with temperature; see Figure 3). In the fast and intermediate exchange regions, the relaxation rate of the $\mathrm{Gd}^{\mathrm{III}}$ electron spin also contributes to the measured $1 / T_{2}$ values. Thus, one needs information on the electronic relaxation rate to extract an accurate value for $k_{\mathrm{ex}}$. We have performed further measurements of the transverse electronic relaxation rates by EPR (unfortunately the magnetic field is quite different from that used in the ${ }^{17} \mathrm{O}$ study) and ${ }^{17} \mathrm{O}$ transverse relaxation rates at three different magnetic fields, in order to achieve this goal. The latter information usually allows better definition of the electronic relaxation contribution, which is the field-dependent term in $1 / T_{2}$. Despite these efforts, the uncertainty in the water exchange rate remained unusually high. Figure 3(c) summarizes the contribution of $k_{\mathrm{ex}}$ and the longitudinal electronic relaxation rate, $1 / T_{1 \mathrm{e}}$, to the overall correlation time that governs the ${ }^{17} \mathrm{O}$ transverse relaxation (1/ $\left.\tau_{\mathrm{s} 1,2}=k_{\mathrm{ex}}+1 / T_{1 \mathrm{e}}\right)$. The plots clearly show that, at all temperatures, the contribution of $1 / T_{1 \mathrm{e}}$ is larger than that of $k_{\mathrm{ex}}$. The relatively fast electronic relaxation is directly evidenced by the $1 / T_{2 \mathrm{e}}$ values measured by EPR (ca. $1.2 \times 10^{10}$ $\mathrm{s}^{-1}$ ) and independent of temperature for $\left[\mathrm{Gd}(\mathrm{DO} 2 \mathrm{~A})\left(\mathrm{H}_{2} \mathrm{O}\right)_{2-3}\right]^{+}$, but in the range $1.3-2.4 \times 10^{9} \mathrm{~s}^{-1}$ for $\left[\mathrm{Gd}(\mathrm{DOTA})\left(\mathrm{H}_{2} \mathrm{O}\right)\right]^{-}(B=0.34 \mathrm{~T})$. Interestingly, the electronic-relaxation times obtained from NMRD profiles for positively charged pyridine containing DO2A-like Gd $^{\text {III }}$ complexes have also been reported to be shorter than for $\left[\mathrm{Gd}(\mathrm{DOTA})\left(\mathrm{H}_{2} \mathrm{O}\right)\right]^{-} \cdot{ }^{[5 b]}$

\section{Implications for Water Proton Relaxivity}

The relaxivity of $\left[\mathrm{Gd}(\mathrm{DO} 2 \mathrm{~A})\left(\mathrm{H}_{2} \mathrm{O}\right)_{n}\right]^{+}$in the $\mathrm{pH}$ region where the complex is fully formed is proportional to its hydration state $(n) .{ }^{[20]}$ However, deprotonation of one of the inner-sphere water molecules in the $\left[\mathrm{Gd}(\mathrm{DO} 2 \mathrm{~A})\left(\mathrm{H}_{2} \mathrm{O}\right)_{n}\right]^{+}$ complexes, leading to the $\left[\mathrm{Gd}(\mathrm{DO} 2 \mathrm{~A})\left(\mathrm{H}_{2} \mathrm{O}\right)_{n-1}(\mathrm{OH})\right]$ spe- cies could modify the relaxivity at high $\mathrm{pH}$. It has been reported in several systems that at high $\mathrm{pH}$ values, $\mathrm{OH}^{-}$ catalyzed proton exchange becomes important and the proton-exchange rate determining the proton relaxivity cannot be simply given by the water-exchange rate. The hydration and hydrolysis equilibria have been studied for the $\mathrm{Eu}^{\mathrm{III}}$ complex, ${ }^{[8]}$ where the tris-aqua form predominates, $K_{2-3}^{298}=$ $4.0 \pm 0.2$. Therefore the value of the hydrolysis constant, $\mathrm{p} K_{\mathrm{a}}^{\mathrm{Eu}}=8.1 \pm 0.3,{ }^{[8]}$ which is an average of the hydrolysis constants for the two species with $n=2$ and 3 weighted by their concentrations, corresponds almost exclusively to the deprotonation of the trihydrated complex, $\left[\mathrm{Eu}(\mathrm{DO} 2 \mathrm{~A})\left(\mathrm{H}_{2} \mathrm{O}\right)_{3}\right]^{+}$. Assuming that the hydration and hydrolysis equilibria of the $\mathrm{Gd}^{\mathrm{III}}$ and $\mathrm{Eu}^{\mathrm{III}}$ complexes are similar, their ionization $\mathrm{p} K_{\mathrm{a}}$ values should also be similar and no changes in relaxivity of $\left[\mathrm{Gd}(\mathrm{DO} 2 \mathrm{~A})\left(\mathrm{H}_{2} \mathrm{O}\right)_{n}\right]^{+}$due to hydrolysis are expected below $\mathrm{pH} \approx 7.1$.

A relaxivity of $6.49 \mathrm{~mm}^{-1} \mathrm{~s}^{-1}$ has been reported previously $^{[5 \mathrm{~b}]}$ for $\left[\mathrm{Gd}(\mathrm{DO} 2 \mathrm{~A})\left(\mathrm{H}_{2} \mathrm{O}\right)_{\mathrm{n}}\right]^{+}$at $\mathrm{pH} 7.0,298 \mathrm{~K}$ and $40 \mathrm{MHz}$. A simulation using an average $n$ of 2.8 and the parameters obtained from the ${ }^{17} \mathrm{O}$ NMR and EPR study estimated a relaxivity of $6.18 \mathrm{~mm}^{-1} \mathrm{~s}^{-1}$ at the same frequency and temperature, consistent with the measured value.

As discussed in the introduction, the $\mathrm{Gd}^{\mathrm{III}}$ complexes with hydration equilibrium were expected to have higher water-exchange rates than chelates with a single hydration state. Such accelerated water exchange could result in a significant increase in proton relaxivity for macromolecular derivatives of such systems where the relaxivity is limited by slow water exchange. For $\left[\mathrm{Gd}(\mathrm{DO} 2 \mathrm{~A})\left(\mathrm{H}_{2} \mathrm{O}\right)_{2-3}\right]^{+}$itself, water exchange has no observable effect on the proton relaxivity since it is exclusively limited by fast rotation (and perhaps by fast electronic relaxation). However, in a macromolecular agent the substitution of $\mathrm{DOTA}^{4-}$ with $\mathrm{DO}^{4} \mathrm{~A}^{2-}$ could result in a significant increase in proton relaxivity, since the water exchange rate would be increased by a factor of 6 .

\section{Conclusion}

The hydration equilibrium and dynamics of a series of $\left[\mathrm{Ln}(\mathrm{DO} 2 \mathrm{~A})\left(\mathrm{H}_{2} \mathrm{O}\right)_{n}\right]^{+}$complexes in aqueous solution at $\mathrm{pH}=6.4-7.0$ was studied by several spectroscopic techniques. An analysis of the lanthanide induced ${ }^{17} \mathrm{O}$ shifts (LIS) of bulk water provided evidence for a decrease in the number of inner-sphere coordinated water molecules in the $\left[\mathrm{Ln}(\mathrm{DO} 2 \mathrm{~A})\left(\mathrm{H}_{2} \mathrm{O}\right)_{n}\right]^{+}$complexes, changing from $n=3$ to $n=2$ near $\mathrm{Eu}^{\mathrm{III}}$. A temperature-dependent UV/Vis study of $\left[\mathrm{Eu}(\mathrm{DO} 2 \mathrm{~A})\left(\mathrm{H}_{2} \mathrm{O}\right)_{\mathrm{n}}\right]^{+}$in aqueous solution provided further evidence for an equilibrium between eight- and nine-coordinate species $(n=2,3)$, with the nine-coordinate $\left[\mathrm{Eu}(\mathrm{DO} 2 \mathrm{~A})\left(\mathrm{H}_{2} \mathrm{O}\right)_{3}\right]^{+}$species predominating.

A variable temperature, multiple field ${ }^{17} \mathrm{O}$ NMR study combined with direct EPR measurements has been used to calculate the parameters characterizing water exchange, rotation and electronic relaxation, all of which influence the proton relaxivity of $\left[\mathrm{Gd}(\mathrm{DO} 2 \mathrm{~A})\left(\mathrm{H}_{2} \mathrm{O}\right)_{2-3}\right]^{+}$. The limited in- 
crease in water exchange rate, $k_{\mathrm{ex}}^{298}=10 \pm 5 \times 10^{6} \mathrm{~s}^{-1}$, compared with $\left[\mathrm{Gd}(\mathrm{DOTA})\left(\mathrm{H}_{2} \mathrm{O}\right)\right]^{-}\left(4.8 \times 10^{6} \mathrm{~s}^{-1}\right)$ is a consequence of the opposite influence of the charge and of the hydration equilibrium. However, as there are 2.8 times as many water molecules on average in the $\left[\mathrm{Gd}(\mathrm{DO} 2 \mathrm{~A})\left(\mathrm{H}_{2} \mathrm{O}\right)_{2-3}\right]^{+}$complex compared with [Gd(DOTA) $\left.\left(\mathrm{H}_{2} \mathrm{O}\right)\right]^{-}(298 \mathrm{~K})$, the overall gain in water exchange is significant. The proton relaxivity of $\left[\mathrm{Gd}(\mathrm{DO} 2 \mathrm{~A})\left(\mathrm{H}_{2} \mathrm{O}\right)_{2-3}\right]^{+}$ is lower than expected, despite the favorable water coordination number of this complex. This reflects a combination of favorable and unfavorable parameters that contribute to its relaxivity, in particular a relatively slow water exchange rate, a short $\tau_{\mathrm{R}}$, and a fast electronic relaxation rate.

\section{Experimental Section}

Sample Preparation: The DO2A $\mathrm{A}^{2-}$ ligand was synthesized by a previously published method. ${ }^{[21]}$ The $\left[\mathrm{Ln}(\mathrm{DO} 2 \mathrm{~A})\left(\mathrm{H}_{2} \mathrm{O}\right)_{n}\right]$ complexes were prepared by mixing equimolar quantities of the ligand and metal solutions, followed by heating $(353 \mathrm{~K})$ for two hours. The $\mathrm{pH}$ was regularly adjusted to $6-7$. The ${ }^{17} \mathrm{O}$ NMR shift measurements for the series of $\mathrm{Ln}^{\mathrm{III}}$ complexes (different from $\mathrm{Gd}^{\mathrm{III}}$ ) were performed on $0.020 \mathrm{~mm}\left[\mathrm{Ln}(\mathrm{DO} 2 \mathrm{~A})\left(\mathrm{H}_{2} \mathrm{O}\right)_{\mathrm{n}}\right]^{+}$solutions $(\mathrm{pH}=7.0)$. The ${ }^{17} \mathrm{O}$ NMR measurements for the $\mathrm{Gd}^{\mathrm{III}}$ complex were performed on a $0.0119 \mathrm{~mol} / \mathrm{kg}\left[\mathrm{Gd}(\mathrm{DO} 2 \mathrm{~A})\left(\mathrm{H}_{2} \mathrm{O}\right)_{\mathrm{n}}\right]^{+}$solution $(\mathrm{pH}=$ 6.53); a $\left[\mathrm{Y}(\mathrm{DO} 2 \mathrm{~A})\left(\mathrm{H}_{2} \mathrm{O}\right)_{\mathrm{n}}\right]^{+}$solution of the same $\mathrm{pH}$ and concentration was used as an external reference. To improve sensitivity, ${ }^{17} \mathrm{O}$-enriched water $\left(10 \% \mathrm{H}_{2}^{17} \mathrm{O}\right.$, Yeda $\mathrm{R} \& \mathrm{D} \mathrm{Co}$.) was added to the solutions resulting in a $2 \%{ }^{17} \mathrm{O}$ enrichment. The absence of free $\mathrm{Ln}^{\mathrm{III}}$ ion was verified with xylenol orange indicator. ${ }^{[22]}$

UV/Visible Spectrophotometry: UV/Visible spectra of a $\left[\mathrm{Eu}(\mathrm{DO} 2 \mathrm{~A})\left(\mathrm{H}_{2} \mathrm{O}\right)_{\mathrm{n}}\right]^{+}$solution $\left(\mathrm{c}_{\mathrm{Eu}}=0.01 \mathrm{M} ; \mathrm{pH}=6.5\right)$ were recorded in the temperature range $277-350 \mathrm{~K}$ on a Perkin-Elmer Lambda 19 spectrometer, using thermostated cells with a $10 \mathrm{~cm}$ optical length $(\lambda=577.5-581.5 \mathrm{~nm})$.

${ }^{17} \mathrm{O}$ NMR Measurements: The ${ }^{17} \mathrm{O}$ NMR shift study of the $\left[\mathrm{Ln}(\mathrm{DO} 2 \mathrm{~A})\left(\mathrm{H}_{2} \mathrm{O}\right)_{n}\right]^{+}$series of complexes was performed using a Bruker AM-400 spectrometer $(9.4 \mathrm{~T} ; 54.2 \mathrm{MHz})$ at $346 \mathrm{~K}$. The samples were introduced in spherical glass bulbs inside $10 \mathrm{~mm}$ NMR tubes, with a drop of nitromethane as an internal shift reference. The spectra were run unlocked. Downfield-induced shifts were taken as positive. A variable temperature ${ }^{17} \mathrm{O}$ NMR study of $\left[\mathrm{Gd}(\mathrm{DO} 2 \mathrm{~A})\left(\mathrm{H}_{2} \mathrm{O}\right)_{n}\right]^{+}$was performed at 3 different magnetic fields using Bruker spectrometers: AMX2-600 (14.1 T, 81.4 MHz), AM$400(9.4 \mathrm{~T}$; $54.2 \mathrm{MHz})$ and a $1.41 \mathrm{~T}, 8.14 \mathrm{MHz}$ electromagnet were connected to an AC-200 console. Bruker VT-1000 temperature control units were used to stabilize the temperature, which was measured by a substitution technique. ${ }^{[23]}$ Bulk water longitudinal relaxation rates, $1 / T_{1}$, were obtained by the inversion recovery method, ${ }^{[24]}$ and transverse relaxation rates, $1 / T_{2}$, by the Carr-Purcell-Meiboom-Gill spin echo technique. ${ }^{[25]}$

Data Analysis: The least-squares fitting was performed by the program Scientist ${ }^{\circledR}$ for Windows ${ }^{\dagger}$ by Micromath ${ }^{\circledR}$, version 2.0 The reported errors correspond to one standard deviation obtained by the statistical analysis.

\section{Acknowledgments}

We thank Dr. Lothar Helm for helpful discussions. We are grateful to the Swiss National Science Foundation, the Office for Education and Science (OFES), Nycomed Amersham Imaging, the Portuguese Foundation of Science and Technology (grant Praxis 2/2.2/ SAU/1194/95), and to the Robert A. Welch Foundation (AT-584) for financial support. This research was carried out in the frame of the EC COST D8 action and the EU-BIOMED program (MACE project).

${ }^{[1]}{ }^{11 \mathrm{a}]}$ R. B. Lauffer, Chem. Rev. 1987, 87, 901. - ${ }^{[1 \mathrm{~b}]}$ J. A. Peters, J. Huskens, D. J. Raber, Prog. Nucl. Magn. Reson. Spectr. 1996, $28,283$.

${ }^{[2]}$ A. D. Sherry, C. F. G. C. Geraldes, in Lanthanide Probes in Life, Chemical and Earth Sciences, Theory and Practice (Eds.: J.-C. G. Bünzli, G. R. Choppin), Elsevier, Amsterdam, 1986, Chapter 4.

[3] [3a] J. M. Lehn, C. O. Roth, Helv. Chim. Acta 1991, 74, 572. ${ }^{[3 b]}$ F. S. Richardson, Chem. Rev. 1982, 82, 541.

[4] J. R. Morrow, L. A. Buttrey, V. M. Shelton, K. A. Berback, J. Am. Chem. Soc. 1992, 114, 1903.

[5] [5a] W. D. Kim, D. C. Hrncir, G. E. Kiefer, A. D. Sherry, Inorg. Chem. 1995, 34, 2225. - [5b] W. D. Kim, G. E. Kiefer, G. E. Maton, K. McMillan, R. N. Muller, A. D. Sherry, Inorg. Chem. 1995, 34, 2233. - ${ }^{[5 c]}$ J. Huskens, D. A. Torres, Z. Kovacs, J. P. André, C. F. G. C. Geraldes, A. D. Sherry, Inorg. Chem. 1997, 36, 1495. - ${ }^{[5 \mathrm{~d}]}$ S. Aime, M. Botta, S. G. Crich, G. B. Giovenzanna, G. Jommi, R. Pagliarin, M. Sisti, Inorg. Chem. 1997, 36, 2992.

[6] S. Amin, H. R. Morrow, C. H. Lake, M. R. Churchill, Angew. Chem. Int. Ed. Engl. 1994, 33, 773.

${ }^{[7]}$ É. Tóth, O. M. Ni Dhubhghaill, G. Besson, L. Helm, A. E. Merbach, Magn. Res. Chem. 1999, 37, 701.

${ }^{[8]}$ C. A. Chang, Y.-H. Chen, H.-Y. Chen, F.-K. Shieh, J. Chem. Soc., Dalton Trans. 1998, 3243.

${ }^{[9]}$ C. N. Reilley, B. W. Good, R. D. Allendoerfer, Anal. Chem. 1976, 48, 1446.

${ }^{[10]}[10 a]$ R. M. Golding, M. P. Halton, Aust. J. Chem. 1972, 25, 2577. - ${ }^{[10 b]}$ A. A. Pinkerton, M. Rossier, S. Stavros, J. Magn. Reson. 1985, 64, 420.

${ }^{[11]}$ B. Bleaney, J. Magn. Reson. 1972, 8, 91.

${ }^{[12]}$ J. Reuben, J. Magn. Reson. 1982, 50, 233.

${ }^{[13]}$ C. F. G. C. Geraldes, A. M. Urbano, M. A. Hoefnagel, J. A. Peters, J. Chem. Soc., Dalton. Trans, 1992, 463, and references therein.

${ }^{[14]}$ G. Geier, C. K. Jorgensen, Chem. Phys. Lett., 1971, 263.

${ }^{[15]}$ N. Graeppi, D. H. Powell, G. Laurenzcy, L. Zékány, A. E. Merbach, Inorg. Chim. Acta, 1994, 235, 311.

[16] [16a] W. D. Horrocks, Jr., D. R. Sudnick, J. Am. Chem. Soc. 1979, 101, 334. - ${ }^{[166]}$ W. D. Horrocks, Jr., M. Albin, Prog. In Org. Chem. 1984, 31, 1.

${ }^{[17]}$ K. Micskei, L. Helm, E. Brücher, A. E. Merbach, Inorg. Chem. $1993,32,3844$.

${ }^{[18]}$ G. Gonzalez, D. H. Powell, V. Tissières, A. E. Merbach, J. Phys. Chem., 1994, 98, 53.

${ }^{[19]}$ J. P. André, H. Maecke, É. Tóth, A. E. Merbach, J. Biol. Inorg. Chem. 1999, 4, 341 .

${ }^{[20]}$ X. Zang, C. A. Chang, H. G. Brittain, J. M. Garrison, J. Telser, M. Tweedle, Inorg. Chem. 1992, 31, 5597.

${ }^{[21]}$ Z. Kovacs, A. D. Sherry, J. Chem. Soc., Chem. Commun. $1995,185$.

[22] G. Brunisholz, M. Randin, Helv. Chim. Acta 1959, 42, 1927.

${ }^{[23]}$ C. Amman, P. Meier, A. E. Merbach, J. Magn. Reson. 1982, 46, 319.

${ }^{[24]}$ R. V. Vold, J. S. Waugh, M. P. Klein, D. E. Phelps, J. Chem. Phys. 1968, 48, 3831.

${ }^{[25]}$ S. Meiboom, D. Gill, Rev. Sci. Instrum. 1958, 29, 688.

Received December 21, 1999

[I99338] 